\title{
Historical climate of the historic church of St. George at Ostropa
}

\author{
Antonina Żaba ${ }^{1, *}$, Michat Marchacz ${ }^{2}$ \\ ${ }^{1}$ Polish National Committee of International Council on Monuments and Sites ICOMOS \\ ${ }^{2}$ Silesian University of Technology, Faculty of Civil Engineering, Akademicka 5, Gliwice, Poland
}

\begin{abstract}
The paper presents investigation studies on the historic climate of the interior of St. George's Church at Ostropa. The church lies on the Wooden Architecture Trail of the Silesian Province within the Gliwice Loop. The building consists of a brick part (presbytery and sacristy) and a wooden part (nave, porch and tower). The shape and size of the church were formed at the end of the 17th century. Most of the decor and furnishings come from that period. Since 2008, the church has been subjected to a wide range of renovation and conservation works. The manager of the object and the conservation office have been entrusted to give special care to the polychromes in the wooden nave, brick presbytery and the main altar. Wooden elements belong to a group of organic hygroscopic materials. They are exposed to the risk of internal damage due to changes in temperature and humidity. The reduction of damage risk involves limiting the scope and dynamics of temperature or humidity changes as compared to the so-called historic climate. The parameters of the historical climate of the object were determined based on the measurement of temperature and humidity inside the investigated object.
\end{abstract}

\section{Introduction}

The area of Upper Silesia is abundant with many ancient wooden objects such as shanties, belfries, chapels, taverns, forester lodges, water mills, antique building museums, garners etc. [1]. They are an essential part of the cultural and historic heritage of this region. One of the subgroups comprises historic wooden churches. All these ancient examples of wooden architecture are contained within the 'Upper Silesian wooden architecture trails' [2].

The Department of Building Engineering and Building Physics, the Faculty of Civil Engineering of the Silesian University of Technology, as part of the research studies involving the exploitation of building objects, has been carrying out works in the aforementioned building objects, including wooden as well as wood and stone churches ${ }^{\dagger}$. Historic objects, along with the furnishings they contain, are often exposed for a long time to the conditions of local climate. They do not have any facilities that can regulate the

\footnotetext{
* Corresponding author: michal.marchacz@polsl.pl

${ }^{\dagger}$ The selected objects and the scope of the undertaken operations were in more detail described in works [3-7]
} 
indoor climate. The exploitation of such objects in cold months can be difficult $[8,9]$. Prior to the introduction of any additional heating facilities to a historic building, a lot of variable features involving its indoor climate have to be determined [10]. The above-mentioned standard recommends defining an appropriate climate by:

- specifying the so-called historic climate,

- defining indoor climate parameters in view of the carried out conservation works,

- determining the parameters of indoor climate in view of comfort of use.

As the next step, the standard recommends finding a compromise between the above. The first of the mentioned steps is to establish the historic climate to which the object has been exposed so far. A change in the thermal and humidity parameters of the interior can adversely affect organic hygroscopic materials. It should be checked what changes in temperature and humidity occurred in the original conditions, i.e. before the planned introduction of heating facilities [11].

The study presents the measurements of temperature and humidity in the historic sacral interior and the attempts to determine its historical climate.

\section{Object of investigations}

The research studies involve the Church of Saint George located at Ostropa, the district of Gliwice. The object is presented in Figs. 1 and 2, and basic information about the church is presented in Tab. $1^{*}$.

\section{Methodology of investigations}

The standard PN EN 15757 [11] contains information on the temperature and relative humidity $(\mathrm{RH})$ ranges recommended for the protection of cultural goods. By limiting temperature and humidity fluctuations, the risk of physical damage caused by stress-strain cycles in organic hygroscopic materials can be reduced. Such materials include e.g. wood, which is the basic material found in the part of historic church examined by the authors.

\subsection{Basic definitions and terms}

The chapter presents the descriptions of main notions contained in the standard PN EN 15757.

Equilibrium moisture content (EMC) is defined in the standard as: "Moisture content at which a hygroscopic material neither loses nor gains moisture from the surrounding atmosphere at given relative humidity and temperature levels".

Historic climate is defined as: "Climatic conditions in a microenvironment where a cultural heritage object has always been kept, or has been kept for a long period of time (at least one year) and to which it has become acclimatized". Basically, these climatic conditions are meaning humidity levels and temperature levels inside the object.

Target level and target range are defined adequately as: " $R H$ level that should be maintained to best ensure preservation" and "Range of RH fluctuations that should be not be exceeded to best ensure preservation". Both of these parameters are determined by: "the historical climate of a given environment that has been proved not be harmful to the preservation of objects". In other words, these parameters should be specified by a qualified conservation professional. Some other terms used in the article are commonly known.

Additional information on the object can be found in the publications $[12,13,14]$ 


\subsection{Defining the target $\mathrm{RH}$ fluctuation range}

Hygroscopic materials are susceptible to the changes of equilibrium moisture. Such changes can bring about the deformation of materials or pose a risk of such deformations or cracks. It is recommended to maintain RH at the level close to the historical climate if the changes of EMC depend on the changes of RH.

It is assumed that for a given room, the stabilization of RH parameters within the target range of the annual change cycles typical of the historical climate may reduce the risk of physical damage [11].

It is assumed that the need to maintain the priority of historical climate is reasoned when: "the conservation status of objects made of organic hygroscopic materials, which have been stored in a specific microclimate for a longer period (at least a year), has been described as satisfactory by qualified specialists in the field of indoor climate and conservation; it is recommended to maintain historical climate of the room, together with average RH levels, variability ranges of natural cycles (annual or daily), as well as the rate of changes "[11]

Other remarks involve the situation when the historical climate is changing. It means, in particular, the reduction of the rate of the introduced changes and allowing for relaxation time constants for the object. The target range of short-term RH fluctuations in the case when $\mathrm{RH}$ is unstable is defined as the 7 th and $93 \mathrm{rd}$ percentile of fluctuations registered in the monitoring period. Short-term fluctuations are viewed as the difference between the current RH reading and the 30-day moving average (MA) of the annual change cycle. The moving average is calculated for 15 days before the current measurement and for 15 days after the current measurement. The current measurement should also be taken into account. By the application of the above procedure, we can rule out $14 \%$ of the largest fluctuations. The target range of RH changes narrowed down in this way is assumed to be safer for the investigated object.

\subsection{Microclimatic measurements}

To conduct long-term temperature and humidity measurements, the use of appropriate measuring equipment is required. It involves costs. The objects discussed in the study are often under-invested (despite their high historical value). The scarcity of funds being at the disposition of the agency managing the object also makes it difficult to carry out measurements inside the object. In the research, commonly available electronic components were applied. Datalogger was built on the basis of the ATtmega328 microcontroller on the Arduino platform. Standards $[15,16]$ set out basic recommendations regarding temperature and humidity measurements as a measuring range, uncertainty, repeatability, resolution or stability. Based on those standards, digital temperature sensors (type ds18B20s, operating temperature $-55^{\circ} \mathrm{C}$ to $+125^{\circ} \mathrm{C}$, accuracy $\pm 0.5^{\circ} \mathrm{C}$ in $-10^{\circ} \mathrm{C}$ to $+85^{\circ} \mathrm{C}$ range, $0.0625^{\circ} \mathrm{C}$ resolution for 12 bit set-up) and digital capacitive temperature and humidity sensors (type DHT22/AM2302, operating range $-40^{\circ} \mathrm{C}$ to $+80^{\circ} \mathrm{C}$ and up $0 \%$ to $99.9 \%$ for humidity, accuracy $\pm 0.5^{\circ} \mathrm{C}$ for temperature, $\pm 2 \%$ max for humidity, $0.1^{\circ} \mathrm{C}$ temperature resolution, $0.1 \%$ humidity resolution) were used. It ensured good measurement precision at a reasonable cost. The flexibility and scalability of the used measuring equipment is also important. Long-term monitoring of temperature and humidity of the examined interior allows to observe the observation of climate changes combined with the reaction of the building. The presented measurements were conducted from June 2015 to July 2016. An hourly interval of results reading was adopted. The temperature of the interior was measured using two sensors type ds1820s. The measurement of humidity (and that of temperature at the same time) was carried out using the sensor type DHT22. The sensors were placed on a tripod 4 meters high with a span of 2 meters. The tripod was located by 
the north wall of the nave covered with valuable medieval paintings [5]. The location of the tripod and the location of the sensors is shown in Fig. 1 and 2.

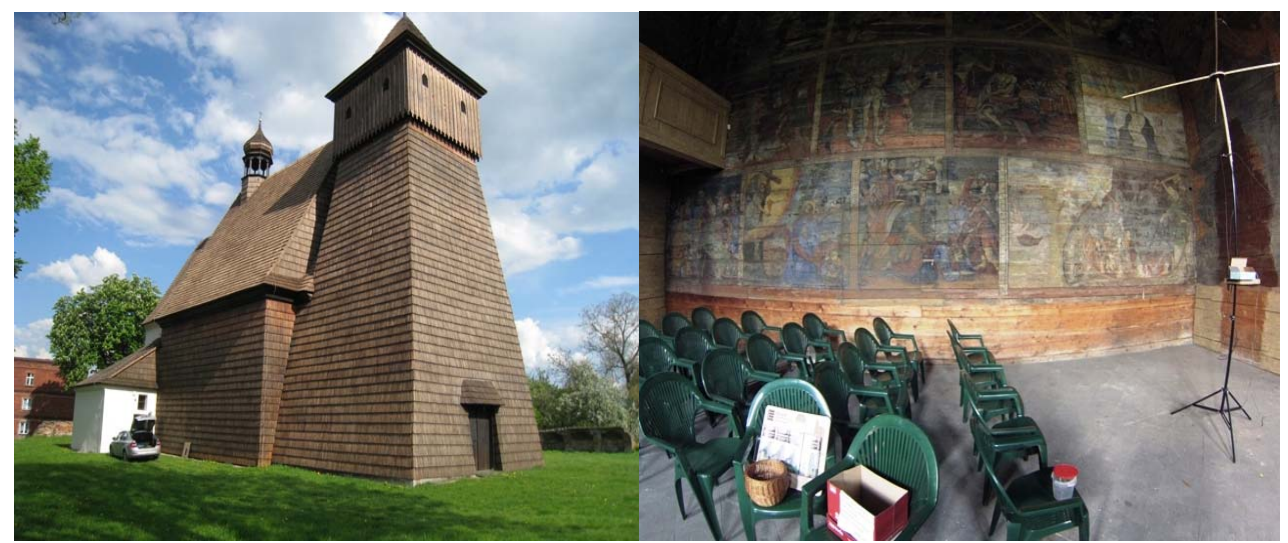

Fig. 1. Ostropa, the Church of Saint George; on the left: view of the object from the north-west; on the right: view of the nave from the side of the presbytery with visible baroque polychrome on the north wall, photo by M. Marchacz.

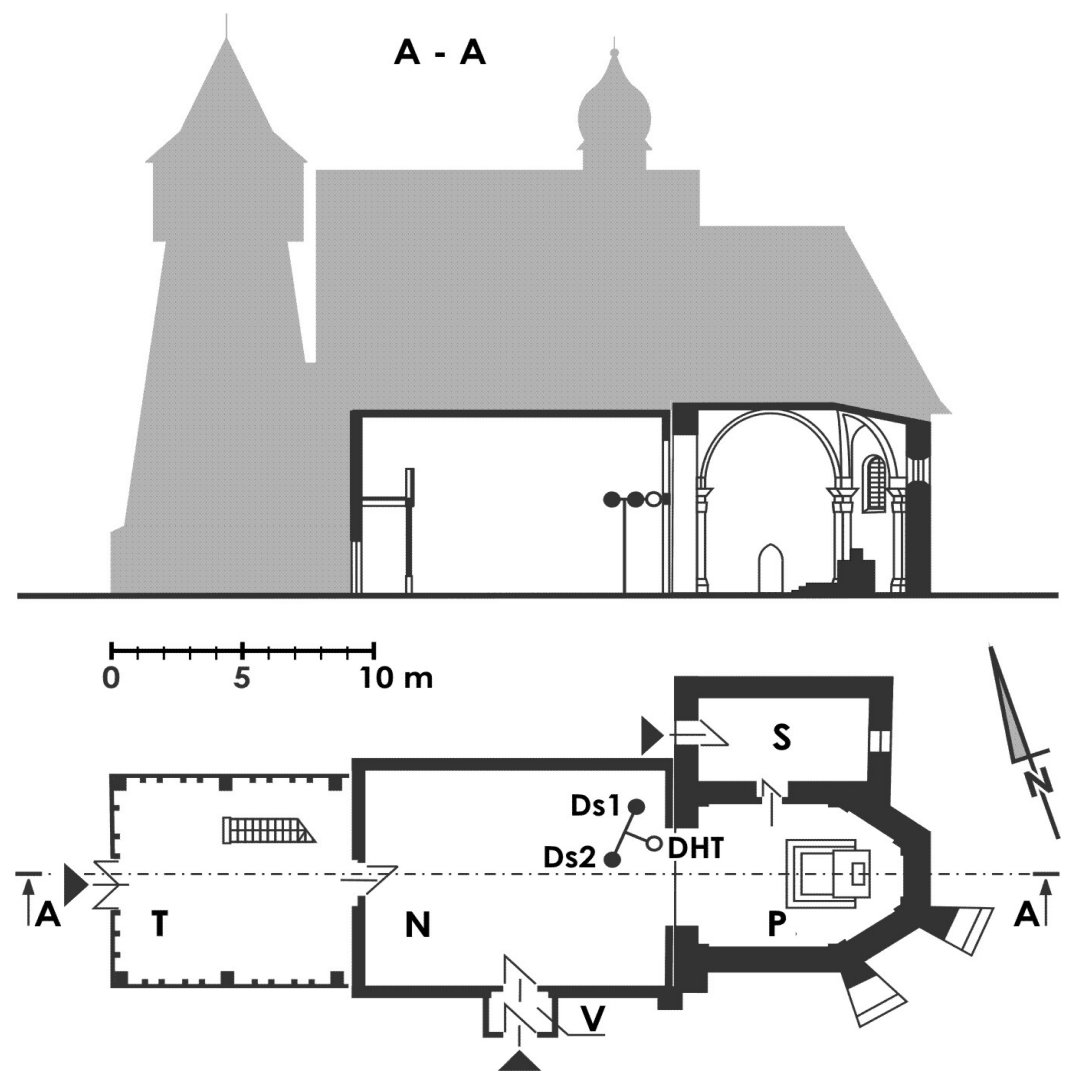

Fig. 2. Ostropa, the Church of Saint George, inventory draft of the object (with the location of the measuring equipment), elaborated by A. Żaba.

Explanation: (T) tower, (N) nave, (V) vestibule - wooden; (P) presbytery, (S) sacristy - masonry; Ds1, Ds2 - temperature sensors, DHT temperature and humidity sensor. 
Table 1. Datasheet with basic information about the object.

\begin{tabular}{|c|c|c|c|c|c|}
\hline \multicolumn{2}{|l|}{ Object } & \multicolumn{4}{|c|}{ Church of St. George / Ostropa (district of Gliwice) } \\
\hline \multicolumn{2}{|l|}{ Dating } & \multicolumn{4}{|c|}{$\begin{array}{l}\text { In the present shape since } 1667 \mathrm{r} . \text {, with tower from } 1544 \\
\text { and reconstructed in } 20^{\text {th }} \text { century - roofs above nave and presbytery, } \\
\text { ridge turret, music gallery. }\end{array}$} \\
\hline \multicolumn{2}{|l|}{ Function } & \multicolumn{4}{|c|}{ Former parish church / now auxiliary church } \\
\hline \multicolumn{2}{|l|}{ Usage } & \multicolumn{4}{|c|}{$\begin{array}{l}\begin{array}{l}\text { Exempted from usage in 1927, since } 2017 \text { used occasionally (weddings, } \\
\text { concerts, lectures) }\end{array} \\
\end{array}$} \\
\hline \multirow{3}{*}{\multicolumn{2}{|c|}{$\begin{array}{l}\text { Parameters of local } \\
\text { climate } \mathbf{C f b} \text { (Köppen- } \\
\quad \text { Geiger) [17] }\end{array}$}} & \multicolumn{2}{|c|}{ Temperature avg: $\left[{ }^{\circ} \mathrm{C}\right]$} & \multicolumn{2}{|c|}{8.6} \\
\hline & & \multicolumn{2}{|c|}{ Rainfall: $[\mathrm{mm} / \mathrm{y}]$} & \multicolumn{2}{|c|}{666} \\
\hline & & \multicolumn{2}{|c|}{ Wind: prevailing force } & \multicolumn{2}{|c|}{ West and Southwestern } \\
\hline \multicolumn{4}{|c|}{ Selected elements of the nave $(\mathrm{N})$} & \multicolumn{2}{|c|}{ Geometrical characteristics of the nave $(\mathrm{N})$} \\
\hline \multirow{2}{*}{ Interior cover } & \multicolumn{2}{|c|}{ Constr. } & \multicolumn{3}{|c|}{ Upper floor: slab ceiling / load bearing beams / battened ceiling } \\
\hline & \multicolumn{2}{|c|}{ Material } & \multicolumn{3}{|c|}{ OSB / wood + steel profiles / wood } \\
\hline \multirow{2}{*}{ Walls } & \multicolumn{2}{|c|}{ Constr. } & \multicolumn{3}{|c|}{ Corner-notched shingled framework / on foundation } \\
\hline & \multicolumn{2}{|c|}{ Material } & \multicolumn{3}{|c|}{ Wood / brick on cement and lime mortar } \\
\hline Flooring & \multicolumn{2}{|c|}{ Material } & \multicolumn{3}{|c|}{ Stone on sand ballast/ground } \\
\hline $\begin{array}{l}\text { Openings (doors, } \\
\text { windows in nave) }\end{array}$ & \multicolumn{2}{|c|}{$\begin{array}{c}\text { Material } \\
\text { and location }\end{array}$} & \multicolumn{3}{|c|}{$\begin{array}{l}\text { All doors in the nave and presbytery are wooden interior doors, } \\
\text { without contact with church's environment and occurring there } \\
\text { climatic conditions. In southern wall of the nave and in the } \\
\text { presbytery are small, singly glazed, air-tight, lathe windows }\end{array}$} \\
\hline \multicolumn{3}{|c|}{ Dimensions $[\mathrm{m}]$} & \multicolumn{3}{|c|}{ Length: 11.5 / Width: 9.4 / Height: 7.5} \\
\hline \multicolumn{3}{|c|}{ Area $\left[\mathrm{m}^{2}\right]$} & 108.1 & Cubature $\left[\mathrm{m}^{3}\right]$ & 810.75 \\
\hline \multicolumn{6}{|c|}{$\begin{array}{l}\text { Overall condition of the object is satisfactory - not found salt efflorescence, biodegradation (fungal } \\
\text { attacks) or failures in the building elements. }\end{array}$} \\
\hline \multicolumn{6}{|c|}{$\begin{array}{l}\text { Protected items (in the nave): polychromes on the north and east walls }\left(17^{\text {th }} \text { century), oil painting }\right. \\
\text { on canvas - east wall }\left(19^{\text {th }} \text { century). }\right.\end{array}$} \\
\hline
\end{tabular}

\section{Results}

All-year results of temperature and relative humidity measurements were subjected to a calculation procedure set out in PN EN 15757. Based on the instantaneous values of temperature and humidity measurements, for each of the measurements the so-called central moving average (MA) was determined. Then, short-term fluctuations were calculated for the values determined in that way. Next, the target range of the fluctuation was determined (adopted as the 7th and 93rd percentile of the registered fluctuations). The obtained results were also used to calculate average temperatures and humidity for the whole year. The borderline results for the entire year are presented in Figs. 3-6. 


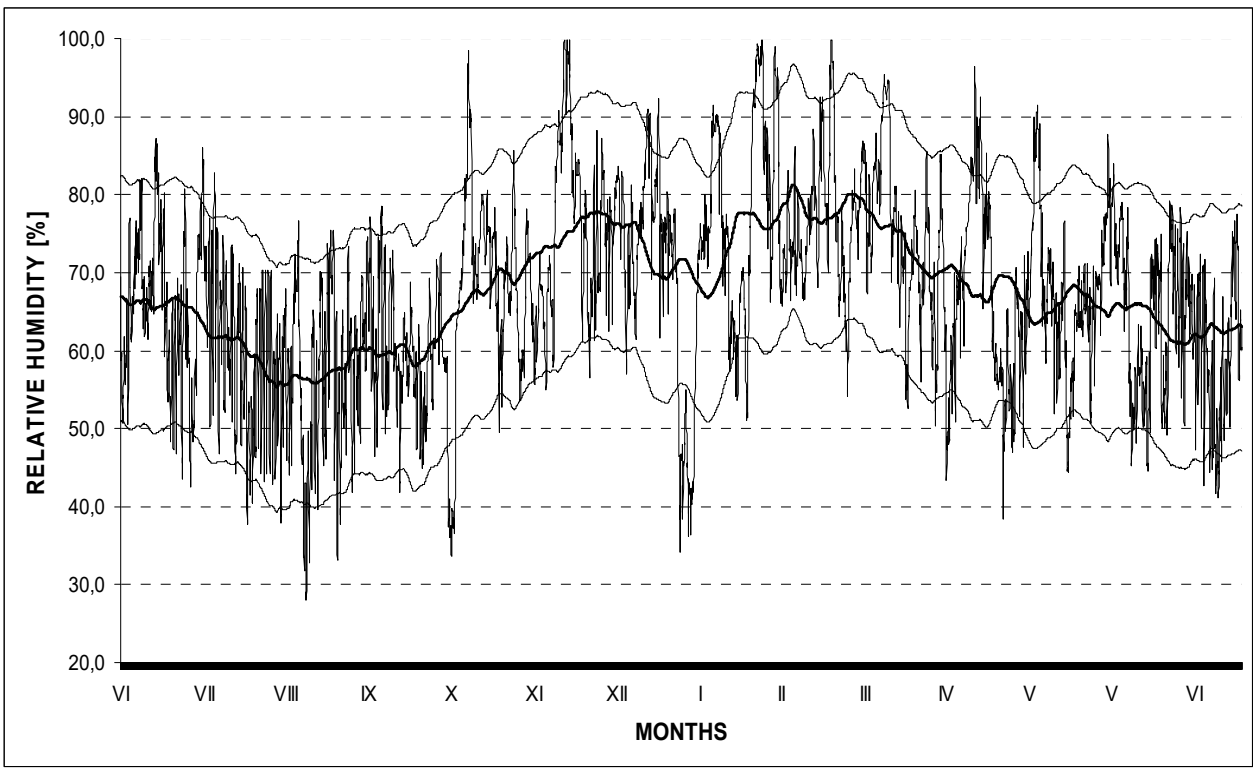

Fig. 3. Instantaneous values short-term measurements together with the values of the annual change cycle and target ranges for the relative humidity $\mathrm{RH}$.

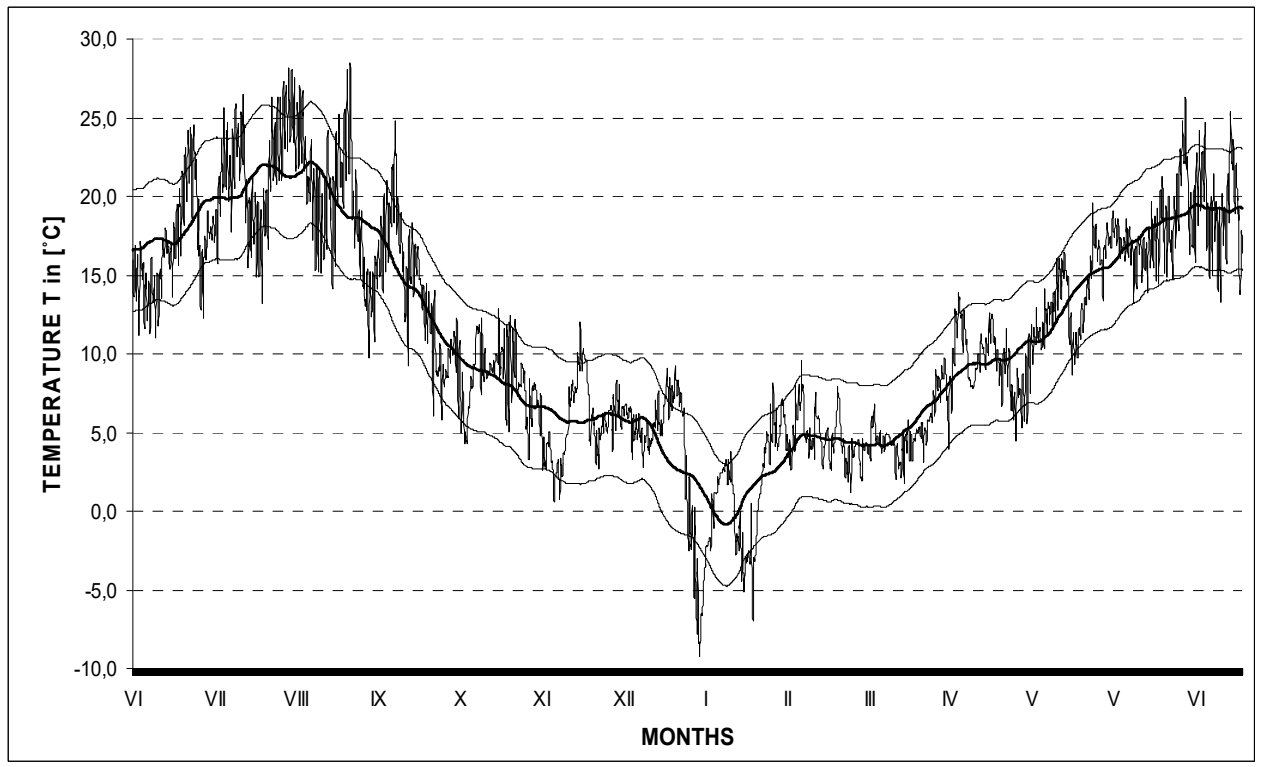

Fig. 4. Instantaneous values of short-term measurements together with the values of the annual change cycle and target ranges for temperature. 


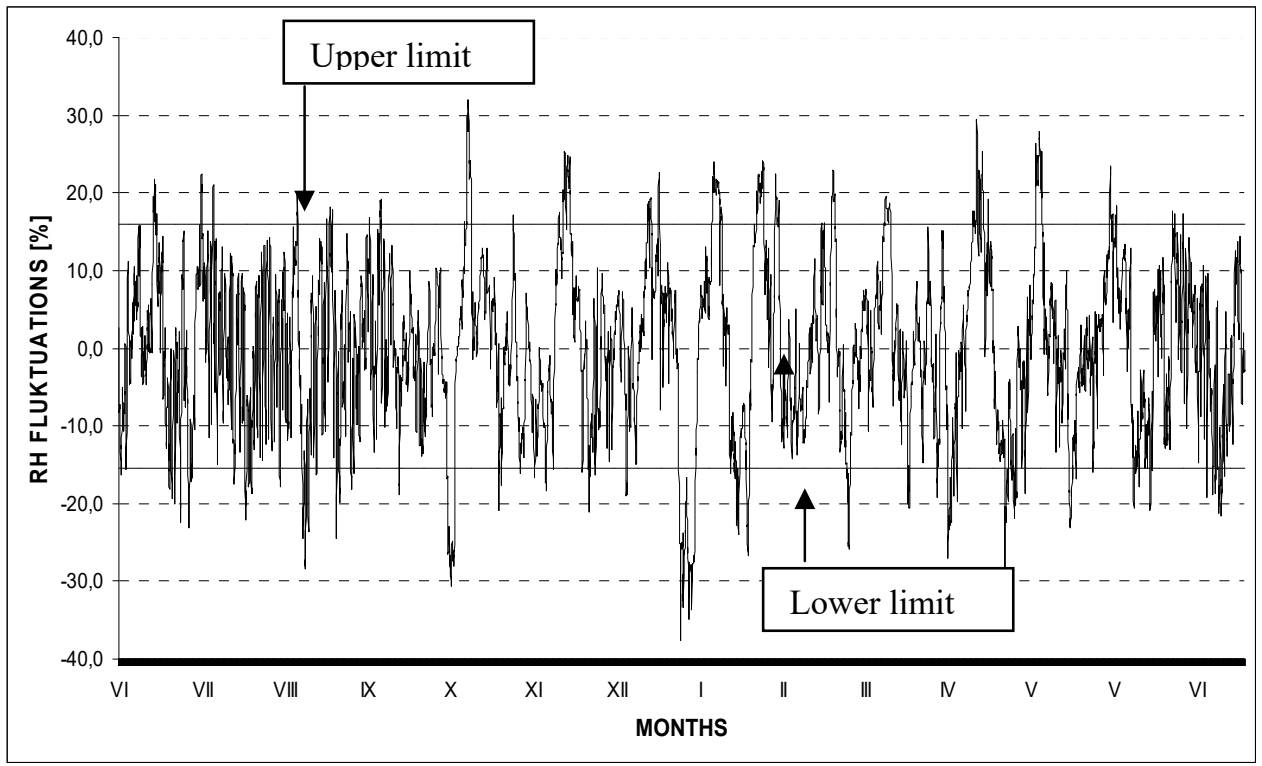

Fig. 5. Short-term fluctuations for the measured relative humidity together with the ranges of lower and upper limits.

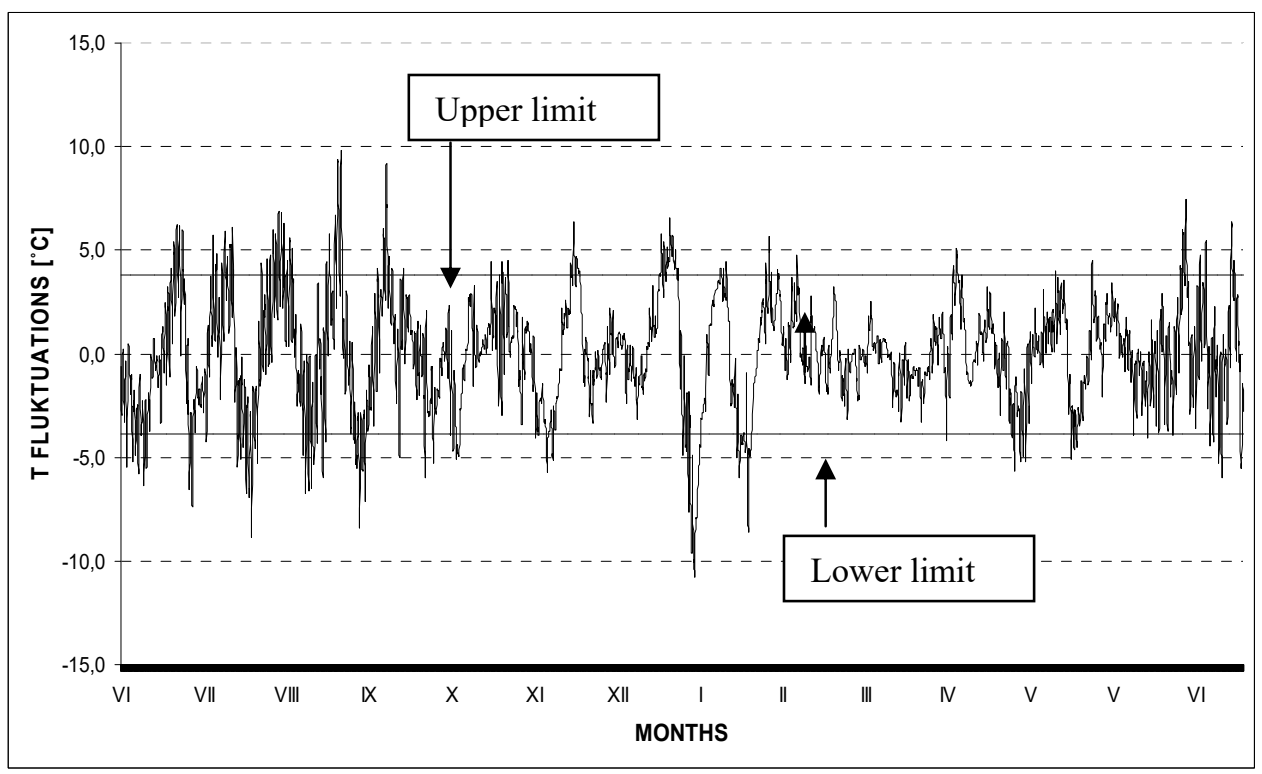

Fig. 6. Short-term fluctuations for the measured temperature together with the ranges of lower and upper limits.

\section{Conclusions}

The material cultural and historical heritage in the form of historic buildings and exhibits being part of their furnishing should be subject to proper protection. This issue is very popular among engineering and conservation professionals [18-21]. The exploitation of historic buildings often involves specific requirements and problems. The indoor climate of 
historic buildings is an important factor affecting their exploitation. This is due to the need to provide the best possible protection for the objects and for the furnishings they contain. On the other hand, such objects are used by people, and hence, an adequate comfort of use should be ensured. The attempts to improve comfort by introducing, e.g. additional, temporary heating facilities may result in rapid changes of the indoor climate parameters [22].

The guidelines on indoor climate parameters in terms of temperature and humidity for the interiors with historic furnishings, such as museum rooms, galleries, archives, libraries are usually quite restricted and endeavor to stabilize the climate [22, 23]. This approach undoubtedly minimizes the risk of damage. For example, the American Society of Heating, Refrigerating and Air Conditioning Engineers assumes no risk of mechanical damage for the AA stabilization class for archives, libraries and museums. It entails, for example, the need to ensure humidity at the level of $50 \%$, assuming annual humidity fluctuations of $0 \%$ and temperatures $\pm 5 \mathrm{C}$. This requires significant expenditure on implementation. The recommendations are based on the assumption presupposing the presence of highperformance air-conditioning and heating systems and a proper structure of the building itself. However, due to the nature of the building (historical buildings with unstable climate), it is not always possible. The analysis of real temperature and humidity parameters in terms of the existing museum collections has in recent years resulted in the attempts to optimize the management of such collections by liberalizing the requirements for certain types of collections. As a target range of relative humidity in rooms, the range of $40-60 \%$ or even wider has been proposed. Also the range of target temperatures is becoming wider. The undertaken steps are based on the assumption of individual adjustment of climate parameters to a given entity [23]. Individual determination of the scope of optimal climatic conditions is based on the material and environmental criteria. The material criterion requires taking into consideration the specificity of a given material and its sensitivity to the changes of relative humidity (taking into account the scale and dynamics of acceptable changes). The environmental criterion in terms of the standard PN EN 15757 is interpreted as historical climate. Basing on the theory of acclimatization of objects, we can state that the object is acclimatized to the conditions of historical climate if in the minimum monitoring period of this climate no new damage is found. The presented research is a part of the trend mitigating the requirements for the protection of cultural goods and making them more real. The methodology presented in the standard may be useful for the manager of the object to ensure a safe range of changes in temperature and humidity in the object, e.g. in the case when it is impossible to comply with stricter requirements. However, it should be remembered that an individual conservation assessment is desirable before deciding on acceptable climate targets.

The instantaneous values of relative humidity and temperature readings, cycles of annual change and target ranges, after the rejection of $14 \%$ of the most unfavorable results, are presented in Fig. 3 and Fig. 4. Seasonal temperature of the annual change cycle varies on average from $-0.9^{\circ} \mathrm{C}$ for January to $22.2^{\circ} \mathrm{C}$ for August. The average temperature of the annual change cycle for a year is $11.5^{\circ} \mathrm{C}$. Similar relationships are demonstrated for relative humidity. The lowest recorded humidity of the annual change cycle is $55.3 \%$ in August, and the highest humidity of the annual change cycle is in February $-81.3 \%$. The average of the whole year is $67.0 \%$. For comparison, the measurements carried out in an unheated historic wooden church in Dębno Podhalańskie [24] indicate similar values of humidity (average relative humidity of the annual change cycle was $71 \%$, while the minimum and maximum values were $55 \%$ and $80 \%$ respectively). Short-term fluctuations for temperature and humidity are shown in Fig. 5 and Fig. 6. Along with the limits of the investigated range ( 7 and 93 percentile), the graph indicates the acceptable range of temperature and humidity changes for the annual cycle. The ranges of short-term fluctuations can be calculated as $16 \%$ and $+15.4 \%$ for relative humidity and $-3.9^{\circ} \mathrm{C}$ to $3.8^{\circ} \mathrm{C}$ for temperature. The wooden 
structure of the nave is not too tight and has slight thermal inertia. At the same time, wood absorbs and releases moisture from the air, making a kind of buffer stabilizing moisture conditions in the interior. The obtained results indicate a wide range of temperature and humidity ranges to which the church is exposed. In the summer of 2016, a renovated wooden altar with polychromes was reintroduced inside the church. Both this element and the antique paintings on the north wall of the wooden nave require further observations regarding their state of preservation. Temperature and humidity spans measured in the interior indicate the need for further, extended monitoring of the interior of the object and its environment. It involves the indoor climate, outdoor climate and moisture level of the envelopes and their surfaces, to determine the exploitation mode of the object, including the presence of people staying there.

\section{References}

1. G. Ruszczyk, Architektura drewniana w Polsce (Muza, Warszawa, 2009)

2. Szlak Architektury Drewnianej Województwa Śląskiego, @: http://www.slaskie.pl/sad/ \{access: 5.03.2018\}

3. A. Żaba, Projekt Szatsza_2015: Kościót Narodzenia Najświętszej Marii Panny. (N2_IPB_EOB student's unpublished work, Faculty of Civil Engineering in Silesian University of Technology in Gliwice, 2015)

4. A. Żaba, Projekt Ostropa_2015: Kościól pw. św. Jerzego w Ostropie. (N1_CKI student's unpublished work, Faculty of Civil Engineering in Silesian University of Technology in Gliwice, 2015)

5. A. Żaba, Malowidła kościoła pw. św. Jerzego: Ostropa, Monografia. Spotkanie z Zabytkiem, 4 (V), Wydział Budownictwa Politechniki Śląskiej, Gliwice, (2011), http://spotkaniezzabytkiem.pl / \{access: 20.03.2018\}

6. M. Marchacz, A. Żaba, Czas. Inż. Ląd. Środ. Archit. t. 33, z. 63, p. 255-262 (3/16)

7. M. Marchacz, A. Żaba, Fiz. Bud. Teor. Prakt. 9-3, 27-32 (2017)

8. PN EN 15251 (2012) Parametry wejściowe środowiska wewnętrznego dotyczace projektowania $i$ oceny charakterystyki energetycznej budynków, obejmujace jakość powietrza wewnętrznego, środowisko cieplne, oświetlenie i akustykę

9. PN EN 7730 (2006) Ergonomia środowiska termicznego - Analityczne wyznaczanie i interpretacja komfortu termicznego z zastosowaniem obliczania wskaźników PMV i PPD oraz kryteriów miejscowego komfortu termicznego

10. PN EN 15759-1 (2012) Konserwacja dóbr kultury - Klimat wewnętrzny - Część 1: Wytyczne dotyczace ogrzewania kościołów, kaplic i innych miejsc kultu

11. PN EN 15757 (2012) Konserwacja dóbr kultury - Wymagania dotyczace temperatury $i$ wilgotności względnej $w$ ograniczaniu mechanicznych uszkodzeń organicznych materiałów higroskopijnych powodowanych oddziaływaniem klimatu

12. E. Kloss, H. Rode, W. Stepf, Die Bau- und Kunstdenkmaler des Kreises Trost-Gleiwitz. [In]: Die Bau- und Kunstdenkmäler Schlesiens, 5. Regierungsbezirk, 220, (W. G. Korn, Kattowitz, Breslau, 1943)

13. E. Dwornik-Gutowska, Powiat gliwicki. [In:] I. Rejduch-Samkowa, J. Samek, Katalog zabytków sztuki w Polsce. Województwo katowickie; t. VI, z. 5, 47, (Instytut Sztuki PAN, Warszawa i Wojewódzki Konserwator Zabytków, Katowice, 1966)

14. S. Gadomski, Drewniane kościoły województwa ślaskiego, 44, (it@tis, Chorzów, 2001)

15. PN EN 16242 (2013-05) Konserwacja dziedzictwa kulturowego - Procedury i przyrzady do pomiaru wilgotności powietrza i wymiany wilgoci między powietrzem a dobrami kultury 
16. PN EN 15758 (2012) Konserwacja dóbr kultury - Procedury i przyrządy do pomiaru temperatury powietrza i powierzchni obiektów

17. https://pl.climate-data.org/location/571/ \{access: 10.03.2018\}

18. H. E. Silva, F. M. A. Henriques, Build. Environ 82, 381-387 (2014)

19. H. E. Silva, F. M. A. Henriques, Ambiente Construído 15/2, 65-77 (2015)

20. B. J. Rouba, Zawilgocenie jako problem $w$ ochronie obiektów budowlanych i zbiorów muzealnych, [In:] Problemy muzeów zwiąane z zachowaniem i konserwacją zbiorów. Materiały VII Międzynarodowej Konferencji Konserwatorskiej, Szreniawa, 36-58 (2016).

21. B. J. Rouba, Zawilgocenie - problem opiekuna kościoła. (Unpublished materials, Commission to: Rada ds. Kultury i Ochrony Dziedzictwa Kulturowego Konferencji Episkopatu Polski do udostępniania zainteresowanym księżom. 30.08.2017)

22. B. J. Rouba, Chłodnictwo \& Klimatyzacja, 7, 48-56 (2017)

23. J. Czop, Warunki mikroklimatyczne $w$ muzeach - nowe rekomendacje. [In:] Ochrona zbiorów. ABC profilaktyki konserwatorskiej w muzeum. Seria wydawnicza Narodowego Instytutu Muzealnictwa i Ochrony Zabytków, 3, 35-43 (2013)

24. R. Kozłowski, Ł. Bratasz, Środowisko w muzeach i obiektach zabytkowych. Kierunki standaryzacji przyjęte przez Europejski Komitet Normalizacyjny, [In:] D. FolgaJanuszewska (red.), Konserwacja zapobiegawcza w muzeach (Krajowy Ośrodek Badań i Dokumentacji Zabytków, Warszawa, 155-164, 2007) 